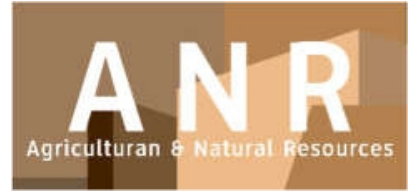

PAPER - OPEN ACCESS

\title{
Dampak Pembukaan Kawasan Hutan Terhadap Erosi
}

$\begin{array}{ll}\text { Author } & : \text { Sari Mayawati dan Jumri } \\ \text { DOI } & : 10.32734 / \text { anr.v2i1.566 } \\ \text { Electronic ISSN } & : 2654-7023 \\ \text { Print ISSN } & : 2654-7015\end{array}$

Volume 2 Issue 1 - 2019 TALENTA Conference Series: Agricultural and Natural Resources (ANR)

\section{(c) $($ )}

This work is licensed under a Creative Commons Attribution-NoDerivatives 4.0 International License.

Published under licence by TALENTA Publisher, Universitas Sumatera Utara

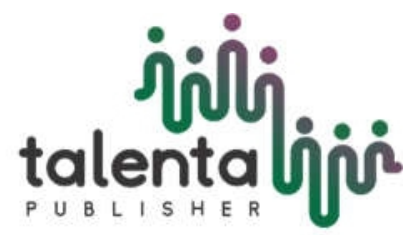




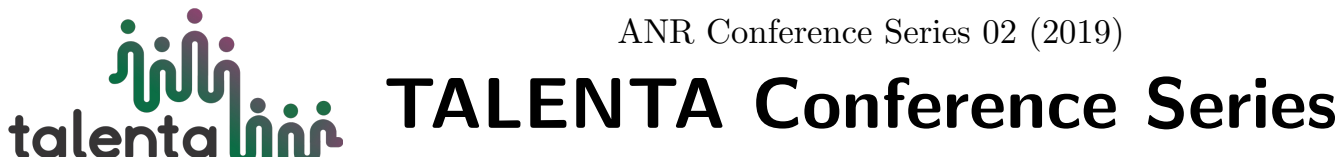

Available online at https://talentaconfseries.usu.ac.id

\section{Dampak Pembukaan Kawasan Hutan Terhadap Erosi}

\author{
(The impact of Forest Area Opening on Erosion)
}

Sari Mayawati dan Jumri*)

${ }^{*}$ Fakultas Pertanian, Jurusan Kehutanan, Universitas Palangka Raya, Indonesia

Email: mayajumri@yahoo.co.id, jumridulamin01@gmail.com

\begin{abstract}
Abstrak
Landasan konstitusional untuk pengolahan hutan tropis di Indonesia merupakan peraturan hukum Indonesia yang tercantum pada UURI no.: 41/1999 yang berisikan ketentuan perihal Kehutanan. Dalam pembukaan suatu areal rimba yang dilakukan oleh perusaha an kehutanan atau non kehutanan tentu akan berdampak positif maupun negatif terhadap lingkungan hutan itu sendiri. Tujuan penelitian ini adalah menganalisis dampak yang terjadi khususnya nilai erosi yang disebabkan dari kegiatan pembukaan hutan/ eksploitasi. Adapun untuk mendapatkan data pembukaan kawasan hutan terhadap erosi dilakukan dengan cara wawancara kepada perwakilan yang terpilih di dalam penelitian ini sekaligus melakukan pengamatan lapangan. Alat analisis data menggunakan [6]: $\mathrm{Kae}(\mathrm{Rp})=(\mathrm{Nda}+\mathrm{Ndp}+\mathrm{Ndn})$. Hasil penelitian menunjukkan nilai kerugiaan erosi akibat dampak pembukaan kawasan hutan perhektar sebesar Rp. 99.469.076.
\end{abstract}

Kata kunci : hutan; pembukaan kawasan; dampak; erosi

\begin{abstract}
The constitutional foundation for tropical forest management in Indonesia is an Indonesian legal regulation listed in the UURI no .: 41/1999 which contains provisions regarding Forestry. In the opening of a jungle area carried out by forestry or non-forestry companies, it will certainly have a positive and negative impact on the forest environment itself. The purpose of this study is to analyze the impacts that occur especially on the value of erosion caused by forest clearing / exploitation activities. As for obtaining data on the opening of forest areas to erosion, interviews were conducted with representatives selected in this study and at the same time conducting field observations. The data analysis tool uses [6]: Kae $(R p)=(N d a+N d p+N d n)$. The results showed the value of erosion losses due to the impact of the opening of one hectare forest area of Rp. 99,469,076.
\end{abstract}

Keywords: Forest; opening of the area; impact; erosion

\section{Pendahuluan}

Pengelolaan hutan lestari harus berpedoman pada peraturan hukum Indonesia yang tercantum pada UURI no. 41/1999 yang berisikan ketentuan perihal Kehutanan [1]. Upaya untuk mencapai tujuan pengelolaan hutan lestari, diperlukan langkah-langkah sebagai berikut: Melaksanakan kegiatan/penerapan silvikultur (TPTI) yang lengkap dan benar, Melaksanakan pemberantasan terhadap adanya kegiatan penebangan liar/illegal logging, Melaksanakan penanggulangan terhadap adanya kebakaran hutan, Melaksanakan suatu tindakan perbaikan dan pemulihan areal rimba serta areal yang terancam punah, Melaksanakan kegiatan reboasasi di areal rimba milik negara dan, Disentralisasi dibidang kehutanan.

Sebagai indikator dalam kegiatan pengelolaan hutan lestari diperlukan adanya: Kerangka ekonomi, mengatur tentang jumlah investasi dan perbaikan sistem penanaman modal dalam pengelolaan hutan berkelanjutan, pengembangan dan penelitian dibidang profesionalisme sumber daya manusia bidang kehutanan, perlu adanya 
perlakuan/kebijakan ekonomi dan bonus lainnya untuk mendorong pembentukan dalam sistem pengelolaan hutan berkelanjutan/ lestari. Kerangka kebijakan dan supremasi hukum yang mengatur tentang pencapaian pengelolaan hutan secara nasional (produksi, konservasi dan perlindungan), keamanan hutan dibuat secara permanen, kepastian terhadap kawasan hutan, pengawasan terhadap pengelolaan hutan, pengawasan terhadap kegiatan eksploitasi hutan, pengendalian terhadap kegiatan perambahan hutan, kesehatan dan keselamatan terhadap pekerja hutan dan partisipasi masyarakat local. Serta perlu adanya Kerangka kelembagaan, yang mendukung pengelolaan hutan berkelanjutan /lestari, tersedianya tenaga profesional di bidang kehutanan, khususnya tenaga teknis yang terlatih disemua bidang untuk melakukan pengelolaan hutan (sarjana kehutanan) dan implementasi dilapangan, adanya kegiatan penelitian dan melaksanakan penyuluhan, membuat rencana dan menerapkan teknologi dalam hal pengelolaan hutan berkelanjutan/lestrai dan dalam hal memanfaatkan hasil hutan secara berkelanjutan, melaksanakan kegiatan evaluasi terhadap rencana yang dibuat, selain itu partisipasi masyarakat dalam pengelolaan hutan seperti perencanaan, pengambilan keputusan, pengumpulan data, pemantauan dan penilaian, memberikan informasi kepada masyarakat tentang pentingnya kebijakan hutan, Undang-Undang dan praktek-praktek pengelolaan hutan lestari.

Implementasi konsep atau pemikiran diatas tentu berdampak positi terhadap kegiatan pembukaan suatu kawasan hutan, namun tidak dapat dihindari juga dampak negatif yang terjadi meskipun pemikiran di atas diaktualisasikan dilapangan. Bertolak dari pemikiran di atas, timbul pertanyaan sebagai berikut: "Seberapa besar dampak negatif yang terjadi akibat pembukaan suatu kawasan hutan dengan luas areal tertentu?"Secara rinci pertanyaan besar di atas, diuraikan sebagai berikut:

- Seberapa besar nilai kerugian akibat erosi terhadap adanya perubahaan warna air sungai?

- Seberapa besar nilai kerugian akibat erosi terhadap adanya pendangkalan sungai (DAS)?

- Seberapa besar nilai kerugian akibat erosi terhadap adanya penurunan produksi ikan hasil tangkapan?

Batasan masalah sebagai objek dalam penelitian ini adalah nilai kerugian lingkungan yang disebabkan oleh erosi, terdiri dari: Nilai dampak akibat erosi terhadap perubahan warna air sungai sehubungan pengunaan air bersih Perusahaan Daerah Air Minum (PDAM), Nilai dampak erosi terhadap pendangkalan air sungai sehubungan penggunaan pelayaran, dan Nilai dampak akibat erosi terhadap pendapatan nelayan sehubungan penurunan produksi ikan hasil tangkapan. Berdasarkan uraian dan batasan masalah di atas, maka penting dilakukan penelitian tentang dampak pembukaan kawasan terhadap erosi.

Tujuan penelitian adalah menganalisis nilai kerugian lingkungan yang meliputi perubahanwarna air sungai, pendangkalan air sungai dan penurunan produksi ikan hasil tangkapan nelayan yang disebabkan oleh erosi pada hutan produksi. Manfaat penelitian adalah memberikan gambaran kepada pemegang kebijakkan (Pemerintah) yang mengelolaan hutan alam Indonesia bahwa dampak negatif yang terjadi sehubungan pembukaan kawasan hutan terhadap perubahan warna air sungai, pendangkalan pada daerah aliran sungai dan muara serta berkurangnya pendapatan nelayan yang disebabkan perubahan letak populasi ikan di permukaan laut.

\section{Metodologi Penelitian}

Penelitian ini dilaksanakan di Kabupaten Kotawaringin Barat Provinsi Kalimantan selama1 (satu) bulan. Metodologi untuk mendapatkan data pembukaan Kawasan hutan terhap erosi yang digunakan yaitu dengan melakukan interviu kepada perwakilan yang terpilih, pimpinan dan manager produksi Perusahaan Daerah Air Minum yang berada di Pangkalan Bun, bertujuan untuk mengetahui seberapa besar kenaikan biaya produksi air bersih dalam satuan Rp/ $\mathrm{M}^{3}$, dan melakukan wawancara dengan pimpinan Syahbandar pelabuhan Kumai, bertujuan untuk mengetahui tentang adanya biaya pengerukkan dan untuk mengetahui besarnya kenaikan harga tiket pelayaran dengan adanya biaya pengerukkan sepanjang daerah aliran sungai Kumai untuk jangka waktu tertentu (10 tahun) serta melakukan wawancara terhadap sample responden nelayan yaitu sebanyak 93 responden/ rumah tangga petani ikan (RTP), yang bertujuan untuk mengetahui perubahan hasil tangkapan ikan nelayan dari waktu kewaktu selama 10 tahun. Analisis data yang dipergunakan didalam penelitian ini yaitu besarnya nilai kerugian lingkungan yang disebabkan oleh erosi pada hutan produksi dihitung dengan cara sebagai berikut: Kae $(\mathrm{Rp})=(\mathrm{Nda}+\mathrm{Ndp}+\mathrm{Ndn})$ [6]. Dimana:

- $\mathrm{Nda}(\mathrm{Rp})=\mathrm{va} \times \mathrm{pb}$,

- $\operatorname{Ndp}(\mathrm{Rp})=$ pfp $x$ tr

- $\operatorname{Ndn}(R p)=$ ppi $\times P_{i}$. 


\section{Keterangan:}

$\mathrm{Nda}=$ Nilai dampak akibat erosi terhadap perubahan warna air Sungai

$\mathrm{Va}=$ Jumlah volume air yang disedot untuk keperluan air baku $\left(\mathrm{m}^{3}\right)$

$\mathrm{Pb}=$ Perubahan biaya pengolahan air bersih $\left(\mathrm{Rp} / \mathrm{m}^{3}\right)$.

$\mathrm{Ndp}=$ Nilai dampak akibat erosi terhadap penggunaan untuk pelayaran selama setahun ( Rp).

Pfp =Frekuensi pelayaran selama setahun.

$\operatorname{tr}=$ Besarnya tarif angkutan manusia/ barang (Rp/tahun).

- $\quad$ Pfp $=$ Fp $\times$ Jp

dimana:

$\mathrm{Fp}=$ Total Frekunsi Pelayaran.

$\mathrm{Jp}=$ Total rata-rata penumpang per 1 kali berangkat.

$\mathrm{Ndn}=$ Nilai dampak akibat erosi terhadap pendapatan nelayan dalam satuan rupiah.

ppi = Penurunan tangkapan ikan oleh nelayan (ton).

$P_{i}=$ Harga ikan sesuai harga pasar.

- $P P i=t_{i} \times r_{i}$.

dimana:

$\mathrm{t}_{\mathrm{i}}=$ Total rata-rata penurunan hasil tangkapan ikan per tahun (Ton).

$\mathrm{r}_{\mathrm{i}}=$ Jumlah RTP (rumah tangga petani ikan).

Sedangkan untuk mengetahi besarnya nilai kerugian lingkungan yang disebabkan oleh erosi pada hutan produksi untuk per tanaman/pohon yaitu dengan menggunakan asumsi jumlah tanaman per hektanya adalah sebanyak 400 pohon[6].

\section{Hasil Dan Pembahasan}

Hasil penelitian tentang dampak erosi yang disebabkan pembukaan kawasa hutan pertanaman secara rinci di sajikan pada Tabel 1.

Dampak kegiatan eksploitasi hutan mengakibatkan laju peresapan air berkurang dan terjadinya peningkatan aliran air permukaan serta perubahan struktur pada permukaan tanah, menimbulkan tajuk terbuka sehingga menyebabkan pengurangan terhadap perlindungan tanah, lahan menjadi terbuka dan mengakibatkan air hujan jatuh secara langsung tanpa adanya penyangga.

Tabel 1. Nilai kerugian ekonomi yang disebabkan pembukaan kawasan hutan pertanaman

\begin{tabular}{lc}
\hline \multicolumn{1}{c}{ Uraian } & $\begin{array}{c}\text { Nilai kerugian akibat erosi per } \\
\text { tanaman (Rp) }\end{array}$ \\
\hline Kenaikkan biaya produksi air bersih & $2.720,00$ \\
Perusahaan daerah air minum (PDAM) & 68,63 \\
Kenaikkan biaya pelayaran pertrif & $2.355,00$ \\
Kerugian nelayan & $5.143,63$ \\
\hline Jumlah
\end{tabular}

Sumber: Data lapangan hasil penelitian

Sehingga dapat menimbulkan banjir, selain itu juga berubahnya sifat-sifat tanah yang disebabkan terjadinya pemadatan tanah dan menyebabkan bahan organik menjadi berkurang serta terjadi erosi permukaan. Kerugian erosi yang dihitung dalam penulisan ini meliputi perubahan warna sungai sehubungan penggunaan air bersih. Hasil penelitian diketahui bahwa air sungai sebelum ada kegiatan penebangan, kondisi air sungai dalam keadaan jernih dan dapat dikonsumsi oleh masyarakat secara langsung. Namun setelah adanya kegiatan penebangan/pembukaan lahan hutan akibat adanya kegiatan eksploitasi hutan mengakibatkan terjadinya kondisi air sungai menjadi keruh dan kondisi ini diperparah terutama pada saat musim penghujan, hal ini diakibatkan erosi permukaan air tanah dari hulu ke hilir sehingga untuk mengkonsumsi air yang layak minum maka perusahaan daerah air minum (PDAM) Kotawaring Barat dalam memproduksi air minum memerlukan biaya pengolahan bahan baku air minun.

Adapun hasil berupa data yang diterima dari instansi Kehutanan Pangkalan Bun untuk tahun 2012 menyatakan realisasi volume dan luas areal tebangan IUPHHK-HA untuk periode 2011 adalah seluas 4.290 Ha dan volume 
tebangan sebanyak 175.682,90 $\mathrm{M}^{3}$ yaitu yang berasal dari IUPHHK-HA diantaranya PT. Karda Traders, PT. Intado Jaya Intiga , PT. Hutanindo Lestari Raya Timber . Hasil penelitian kerugian erosi terhadap penambahan biaya pengolahan air baku perusahaan daerah air minum Tahun 2006-2010[3] yang digunakan untuk menjadikan air layak konsumsi, maka diperlukan biaya rata-rata per tahun sebesar Rp. 5.545.691.406. Sedangkan total volume air yang disedot yang merupakan air sebagai bahan dasar yang dipergunakan untuk pembuatan air bersih (PDAM) adalah 2.702.345 $\mathrm{M}^{3}$. Dengan demikian, maka didalam pengolahan air layak konsumsi terdapat perubahan biaya produksi per $\mathrm{M}^{3}$ adalah sebesar Rp. 30,23. Perubahan biaya tersebut sebagai dampak erosi untuk pengolahan dan pembelian bahan kimia yang dipergunakan untuk proses pengolahan air bersih. Diasumsikan 1 hektar lahan ditanami pohon sebanyak 400 pohon dengan jarak (5X5) $\mathrm{m}[6]$, diperoleh dampak erosi terhadap perubahan warna air sungai sehubungan penggunaan air bersih (Nda pertanaman) Rp. 2.720 \{diperoleh dari : $2.702 .345 \mathrm{M}^{3}$ (volume air baku)X Rp. 30,23 (perubahan biaya produksi/M $\mathrm{M}^{3}$ ) : $4.290 \mathrm{Ha}$ (luas tebangan tahun 2011) : 7 pohon ( jumlah tanaman/pohon per/Ha)\}.

Hal ini sesuai pendapat [2], bahwa perbandingan hasil endapan tersuspensi antara daerah aliran sungai (DAS) yang dieksploitasi dan daerah didekatnya yang tidak dieksploitasi terjadi empat kali setelah terjadi kegiatan eksploitasi, lima kali setelah eksploitasi pada jarak 37 meter dari jalan dan 18 kali lipat selama lima bulan kegiatan eksploitasi daerah aliran yang tersisa. Namun setahun setelah eksploitasi berhenti, jumlah endapan bulanan terbesar hanya 8,6 kali lipat endapan di daerah yang tidak dieksploitasi dan proses pemulihan berlangsung secara perlahan. Tebang pilih secara komersial di daerah aliras sungai (DAS) hulu menyebabkan banyak terjadi tumpukan sedimentasi dan perubahan warna air.

Dampak erosi terhadap pelayaran disebabkan terjadi tumpukan sedimentasi pada daerah aliran sungai (DAS) Kumai Kotawaringin Barat yang bermuara ke laut mengakibat gangguan terhadap frekuesi pelayaran. Sehingga untuk memperlancar arus pelayaran diperlukan pengerukan sedemintasi. Dari hasil penelitian diketahui biaya pengerukan sungai untuk jangka waktu sepuluh tahun (2001-2011) sebesar Rp. 9.263.087.000. Hasil penelitian kerugian erosi terhadap pelayaran (Ndp) adalah sebesar Rp.524.788.700 \{diperoleh dari Rp. 926.308 .700 (biaya pengerukan Rp.143.400 (rata-rata tariff x 350 orang (jumlah penumpang pertrip) x 8 (perubahan frekuensi pelayaran pertahun)\}. Sehingga biaya rata-rata pertanaman sebesar Rp. 68,63 \{diperoleh dari: Rp.524.788.700 (Ndp) : 19.117Ha (luas total lahan terbuka) : 400 pohon (jumlah tanaman/pohon perhektar) \}.

Sedangkan luas lahan yang terbuka akibat alih fungsi (Hutan menjadi perkebunan sawit dan pemukiman) adalah seluas 19.117 Ha[4]. Terbuka lahan hutan mengakibatkan erosi sehingga air sungai menjadi keruh, dengan demikian menyebabkan populasi ikan menjauh dari muara. Kondisi semacam ini sangat berpengaruh terhadap biaya produksi nelayan biaya khususnya bahan bakar minyak (BBM) menjadi bertambah dan pendapatan hasil tangkapan nelayan berkurang rata-rata pertahun mencapai $50 \mathrm{~kg}$. sedangkan besanya biaya dari hasil kerugian erosi terhadap hasil perolehan tangkapan nelayan (Ndn) untuk tahun 2011, adalah sebesar Rp. 18.009.000.000 \{diperoleh dari: $500 \mathrm{~kg}$ (rata-rata penurunan hasil tangkapan ikan pertahun) x 1.305 RTP (jumlah rumah tangga nelayan) x Rp. 27.600 (harga ikan perkg)\}. Sehingga diperoleh bahwa besarnya nilai kerugian erosi terhadap hasil tangkapan nelayan pertanaman adalah sebesar Rp. 2.355 \{diperoleh dari : Rp.18.009.000.000(Ndn) : 19.117 Ha (luas total lahan terbuka): 400 pohon (jumlah tanaman/pohon perhektar)\}.

\section{Kesimpulan}

Berdasarkan hasil penenlitian dapat disimpulkan bahwa besarnya dampak erosi terhadap kenaikkan biaya produksi air bersih perusahaan daerah air minum dihitung berdasarkan pertanaman akibat adanya pembukaan suatu kawasan hutan adalah sebesar Rp. 2.720, dampak erosi terhadap besarnya kenaikkan biaya pelayaran pertrif (satu kali jalan) pertanaman akibat adanya pembukaan suatu kawasan hutan adalah sebesar Rp. 68,63, dampak erosi terhadap kerugian nelayan hasil tangkapan ikan pertanaman akibat adanya pembukaan suatu kawasan hutan adalah sebesar Rp. 2.355. Sehingga jumlah dampak erosi yang terjadi akibat adanya pembukaan suatu kawasan hutan adalah untuk pertanamannya adalah Rp. 5.143,63.

\section{Ucapan Terimakasih}

Bersamaan dengan hasil penelitian ini tak lupa penulis mengutarakan terima kasih banyak kepada Bapak Ketua Perguruan Tinggi Palangka Raya (Rektor UPR), Bapak Dekan Fakultas Pertanian Universitas Palangka Raya, Ibu 
Ketua Jurusan Kehutanan Fakultas Pertanian Universitas Palangka Raya, Bapak Ketua KOMHINDO, Bapak/Ibu Panitia Seminar KOMHINDO III dan Bapak/Ibu Dosen sejawat Jurusan Kehutanan Fakultas Pertanian Universitas Palangka Raya.

\section{Referensi}

[1] Undang-undang No. 41/1999, Tanggal 30 September 1999, “Tentang: Kehutanan. Sekretariat Kabinet Republik Indonesia”. Jakarta, 1999.

[2] Douglas, I., Spencer,T., Greer, T., Bidin, K.,Sinun,W.dan Wong, W.M, “The Impact of Selective Commercial Logging On Stream Hydrology, Chemistry And Sediment Loads In the Ulu Segama Rainforest, Sabah, Malaysia.” Phil. Trans. R.Soc. Lond. B 335: 397-406, 1992.

[3] PDAM, "Laporan Audit Keuangan. Perusahaan Daerah Air Minum.” Pangkalan Bun, 2006-2010

[4] PT. Karda Traders, "Rencana Kerja Tahunan Usaha Pemanfaatan Hasil Hutan Kayu Dalam Hutan Alam Pada Hutan Produksi Tahun 2011." Pangkalan Bun, 2011

[5] Suparmoko, M, ’Ekonomi Sumber Daya Alam Dan Lingkungan (Suatu Pendekatan Teoritis).” BPFE .Yogyakarta. p. 565, 1997

[6] Sari Mayawati, "Price Determination of Sustainable Wood in Forest Conservation Efforts." Jurnal Academic Research International Vol. 5(5) September 2014, 2014 